\title{
Stabilitas Laju Fotosintesis dan Produktivitas Rimpang Genotipe Curcuma aeruginosa dan Curcuma zanthorrhiza
}

\author{
Stability of Photosynthetic Rate and Rhizome Yield of \\ Curcuma aeruginosa and Curcuma zanthorrhiza Genotypes
}

\author{
Djarot Sasongko Hami Seno ${ }^{1 *}$, Mohamad Rafi ${ }^{2,3}$, Maria Bintang², Popy Asri Kurniatin ${ }^{2}$, dan Waras Nurcholis ${ }^{1,2}$ \\ ${ }^{1}$ Departemen Biokimia, Fakultas Matematika dan Ilmu Pengetahuan Alam, Institut Pertanian Bogor \\ (Bogor Agricultural University), Jl. Agatis, Kampus IPB Darmaga, Bogor 16680, Indonesia \\ ${ }^{2}$ Pusat Studi Biofarmaka Tropika, Institut Pertanian Bogor \\ (Bogor Agricultural University), Jl. Taman Kencana No. 3, Kampus IPB Taman Kencana, Bogor 16128, Indonesia \\ ${ }^{3}$ Departemen Kimia, Fakultas Matematika dan Ilmu Pengetahuan Alam, Institut Pertanian Bogor \\ (Bogor Agricultural University), Jl. Agatis, Kampus IPB Darmaga, Bogor 16680, Indonesia
}

Diterima 19 Maret 2020/Disetujui 13 April 2020

\begin{abstract}
Curcuma aeruginosa Roxb. rhizome is an essential herb material with significant antimicrobial, anticancer, and

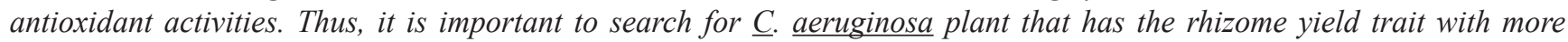
excellent stability in changing environmental situations. This research aimed to evaluate the genotype $x$ environment interaction using additive main effects and multiple interaction (AMMI) analysis for photosynthetic rate and rhizome yield of $\underline{C}$. aeruginosa genotypes. Twenty clones of $\underline{C}$. aeruginosa plus three control varieties of $\underline{C}$. zanthorrhiza Roxb. were evaluated in three environments (Bogor, Cianjur, and Sukabumi) using a randomized complete block design with three replicates. The photosynthetic rate and rhizome yield showed significantly $(p<0.01)$ genotype $x$ environment interaction. The AMMI2 explained 100\% variability of the photosynthetic rate and rhizome yield parameters. G2, G10, G12, G13, G14, G16, G17, G19, and G20 were stable genotypes for rhizome yield based on AMMI analyses. Meanwhile, the stable genotype in photosynthetic rate recorded in $G 4, G 5, G 6, G 8, G 11, G 13$, and G14.
\end{abstract}

Keywords: AMMI, genotypes, multilocation trials, pink and blue ginger, varieties

\section{ABSTRAK}

Rimpang temu hitam (Curcuma aeruginosa Roxb.) merupakan bahan baku herbal penting yang berkhasiat sebagai antimikroba, antikanker, dan antioksidan. Dengan demikian, penting untuk mendapatkan tanaman temu hitam yang memiliki produktivitas rimpang dengan stabilitas yang luas pada kondisi lingkungan yang beragam. Penelitian ini bertujuan untuk mengevaluasi interaksi genotipe $x$ lingkungan menggunakan analisis additive main effects and multiple interaction (AMMI) terhadap karakter laju fotosintesis dan produktivitas rimpang genotipe temu hitam. Dua puluh genotipe temu hitam dan tiga varietas temulawak (ㄷ. zanthorrhiza Roxb.) dievaluasi di tiga lokasi percobaan (Bogor, Cianjur, dan Sukabumi) menggunakan rancangan acak kelompok lengkap teracak dengan pengulangan tiga kali. Interaksi genotipe $x$ lingkungan memberikan pengaruh yang sangat nyata $(p<0.01)$ terhadap laju fotosintesis dan produktivitas rimpang. AMMI2 dapat menjelaskan $100 \%$ keragaman terhadap karakter laju fotosintesis dan produktivitas rimpang. G2, G10, G12, G13, G14, G16, G17, G19, dan G20 merupakan genotipe yang stabil pada produktivitas rimpang berdasarkan analisis AMMI. Karakter laju fotosintesis yang stabil ditemukan pada genotipe G4, G5, G6, G8, G11, G13, dan G14.

Kata kunci: AMMI, genotipe, temu hitam, uji multilokasi, varietas

\footnotetext{
* Penulis untuk korespondensi. e-mail: hamisenodjarot@gmail.com
} 


\section{PENDAHULUAN}

Temu hitam atau temu ireng (Curcuma aeruginosa Roxb.) merupakan salah satu jenis tanaman obat dalam bentuk rimpang dari keluarga Zingiberaceae. Tanaman tersebut tumbuh subur di Indonesia, namun penggunaannya masih terbatas khususnya pada industri obat tradisional. Penelitian terbaru menunjukkan beberapa khasiat farmakologi dari rimpang tanaman temu hitam, beberapa diantaranya adalah minyak atsiri sebagai antimikroba (Akarchariya et al., 2017) dan pemutih kulit (Srivilai et al., 2017), ekstrak etanol sebagai antikanker dan antioksidan (Nurcholis et al., 2016c, 2017a). Besarnya potensi khasiat temu hitam perlu dikembangkan lebih luas, salah satunya dengan mempersiapkan varietas temu hitam menjadi bahan baku rimpang yang unggul untuk industri herbal.

Varietas temu hitam sampai saat ini belum ada di Indonesia (Pusat Perlindungan Varietas Tanaman dan PerizinanPertanian, 2019). Dengandemikian, pengembangan varietas sangat diperlukan untuk menyediakan bahan baku rimpang temu hitam yang terstandar. Salah satu tahap penting dalam pengembangan varietas adalah uji multilokasi, yang dapat digunakan untuk menentukan suatu genotipe spesifik lokasi atau mampu beradaptasi secara luas (Aarthi et al., 2020). Selain itu, pengujian multilokasi dapat mengindentifikasi lingkungan yang paling baik untuk karakter tertentu berdasarkan interaksi antara genotipe $\mathrm{x}$ lingkungan. Varietas temu hitam belum ada, sehingga temulawak dipilih sebagai pembanding dalam uji multilokasi karena dari keluarga yang sama (Zingiberaceae) dan memiliki karakteristik tanaman yang serupa baik rimpang yang dihasilkan serta khasiat untuk kesehatan (Nurcholis et al., 2012, 2018). Rimpang merupakan bagian tanaman yang digunakan untuk pengobatan pada tanaman temu hitam dan temulawak. Rimpang merupakan bentuk simpanan, sehingga besarnya diduga akan sangat dipengaruhi oleh laju fotosintesis. Sampai saat ini pengaruh laju fotosintesis terhadap produktivitas rimpang temu hitam dan temulawak belum ada yang melaporkan, namun pada beberapa tanaman lain telah dilaporkan diantara pada Rubia yunnanensis (Miao et al., 2020) dan C. alismatifolia (Chidburee et al., 2007). Dengan demikian, produktivitas rimpang dan laju fotosintesis merupakan karakter penting yang dipilih dalam uji multilokasi. Analisis multivariat yaitu additive main effect and multiple interaction (AMMI) saat ini merupakan metode statistik yang cukup baik dalam menjelaskan interaksi antara genotipe dan lingkungan (Sharifi et al., 2017). Dengan demikian, penelitian ini bertujuan untuk menduga interaksi genotipe $\mathrm{x}$ lingkungan menggunakan analisis AMMI pada karakter laju fotosintesis dan produktivitas rimpang dari 20 genotipe temu hitam pada tiga lokasi percobaan.

\section{BAHAN DAN METODE}

Bahan utama yang digunakan dalam penelitian ini adalah 20 genotipe temu hitam (seleksi hasil eksplorasi dan analisis performa) koleksi Tim Biokimia Pertanian dan Pusat Studi Biofarmaka Tropika yang diberi kode G1-G20. Selain itu, penelitian juga menggunakan kontrol yaitu temulawak (C. zanthorrhiza Roxb.) varietas Cursina 1, Cursina 2, dan Cursina 3 yang diperoleh dari Balai Penelitian Tanaman Rempah dan Obat, Bogor, Indonesia.

Lokasi penelitian untuk pengujian multilokasi dilakukan di Bogor, Cianjur, dan Sukabumi dengan informasi kondisi lokasi selama pengujian (2018-2019) disajikan pada Tabel 1. Percobaan disetiap lokasi dilakukan dengan rancangan kelompok lengkap teracak dengan tiga ulangan. Satu rimpang dengan bobot 30-50 g digunakan per satuan percobaan. Setiap ulangan digunakan 5 tanaman dengan ukuran jarak antara genotipe $60 \mathrm{~cm}$ dan jarak dalam satuan percobaan $50 \mathrm{~cm}$. Total tanaman sebanyak 345 tanaman dengan luasan keseluruhan adalah $125 \mathrm{~m}^{2}$. Sementara untuk metode budidaya dilakukan secara organik sesuai Nurcholis et al. (2019). Bibit yang digunakan adalah rimpang induk yang berumur 9 bulan setelah tanam (BST). Pemupukan dilakukan 1 kali pada awal tanam sebanyak $1 \mathrm{~kg}$ lubang tanam $^{-1}$. Pemeliharaan dilakukan setiap bulan selama masa pertumbuhan dengan melakukan penyiangan gulma dan pembumbunan. Panen rimpang dilakukan pada tanaman umur 9 BST. Laju fotosintesis diukur pada tanaman umur 5 bulan setelah tanam dengan menggunakan alat $\mathrm{Li}$-Cor portable photosynthesis system (model L1-6400XT, Li-Cor Inc., Lincoln, NE). Sementara untuk produktivitas rimpang ditentukan setelah panen yaitu tanaman umur 9 bulan setelah tanam. Produktivitas rimpang diukur dalam g per rumpun.

Analisis data dilakukan dengan menggunakan aplikasi R. Stabilitas laju fotosintesis dan produktivitas rimpang 20 genotipe temu hitam dan 3 varietas temulawak ditentukan dengan analisis model AMMI dengan menggunakan perangkat lunak PBSTAT-GE (www.pbstat.com).

\section{HASIL DAN PEMBAHASAN}

Rimpang merupakan tempat penyimpanan (sink) pada tanaman temu hitam. Simpanan metabolit dilakukan dari akumulasi proses fotoasimilasi dari sel mesofil daun (source) yang jumlah distribusi asimilat sangat bergantung pada salah satunya dari laju fotosintesis (Chidburee et al., 2007; Pavlović et al., 2019). Dengan demikian, pemilihan karakter produktivitas rimpang dan laju fotosintesis merupakan hal penting untuk dipilih dalam upaya mendapatkan genotipe temu hitam yang stabil dan adaptif pada suatu lokasi budidaya. Hal tersebut tentunya penting dalam pengembangan temu hitam sebagai bahan baku herbal, khususnya mendapatkan informasi genotipe yang stabil dan adaptif sehingga dapat ditentukan pengembangan yang lebih tepat dalam upaya mendapatkan varietas unggul temu hitam Indonesia. Selain dari aspek genotipe, manfaat penelitian ini juga dapat diperoleh dari aspek lokasi yaitu mendapatkan gambaran sentra budidaya temu hitam yang lebih sesuai untuk menghasilkan produktivitas rimpang yang tinggi sehingga bernilai secara ekonomi.

ANOVA menunjukkan adanya pengaruh sangat nyata $(\mathrm{p}<0.001)$ pada karakter produktivitas rimpang untuk lokasi dan interaksi genotipe x lingkungan (Tabel 2). Sementara pada karakter laju fotosintesis, lokasi, ulangan/lokasi, dan 
Tabel 1. Informasi kondisi lokasi pengujian

\begin{tabular}{llccccc}
\hline Lokasi & Karakterisasi lahan & Lintang & Bujur & $\begin{array}{c}\text { Ketinggian } \\
\text { tempat } \\
(\mathrm{m} \mathrm{dpl}) *\end{array}$ & $\begin{array}{c}\text { Curah } \\
\text { hujan } \\
(\mathrm{mm}) \#\end{array}$ & $\begin{array}{c}\text { Suhu } \\
\left({ }^{\circ} \mathrm{C}\right) \#\end{array}$ \\
\hline Bogor & Kebun Unit Konservasi Budidaya Biofarmaka IPB & 6.55 LS & 106.72 BT & 141 & $51-671$ & $25.8-27.0$ \\
Cianjur & Kebun Percobaan Pasir Sarongge IPB & 6.77 LS & 107.05 BT & 1083 & $46-552$ & $20.7-22.4$ \\
Sukabumi & Kebun milik petani & 6.87 LS & 106.80 BT & 493 & $38-651$ & $19.4-23.1$ \\
\hline
\end{tabular}

Keterangan: *dpl = di atas permukaan laut. \#sumber = Badan Meteorologi Klimatologi dan Geofisika, Stasiun Klimatologi Bogor, Data Curah Iklim Bulanan 2018-2019

interaksi genotipe $\mathrm{x}$ lingkungan memberikan pengaruh yang sangat nyata $(\mathrm{p}<0.001)$ (Tabel 2). Pada interaksi genotipe $\mathrm{x}$ lingkungan, $\mathrm{PC} 1$ menggambarkan pengaruh yang nyata $(\mathrm{p}$ $<0.001$ ) baik pada karakter produktivitas rimpang dan laju fotosintesis.

Genotipe G11 menghasilkan rerata produktivitas rimpang tertinggi di semua lokasi sebesar $612 \mathrm{~g}$ per rumpun (Tabel 3). Bogor merupakan lokasi yang menghasilkan rata-rata produktivitas rimpang tertinggi nyata $(\mathrm{p}<0.05)$ diikuti oleh lokasi Sukabumi dan Cianjur. G11, G4, G8, G7, G18, G9, G3, G13, G12, dan G14 menghasilkan produktivitas rimpang tertinggi di lokasi Bogor. Pada lokasi Cianjur, genotipe G6 menghasilkan produktivitas rimpang tertinggi yang tidak berbeda nyata pada $\alpha=0.05$ dengan kontrol temulawak varietas Cursina 2 dan Cursina 3. Sementara, pada lokasi Sukabumi menunjukkan bahwa G6 menghasilkan produktivitas rimpang tertinggi namun tidak berbeda nyata dengan sampel yang lainnya $(\mathrm{p}<0.05)$. Temu ireng dan temulawak merupakan tanaman dengan spesies yang berbeda, namun satu keluarga Zingiberaceae. Kedua tanaman tersebut memiliki bentuk rimpang dan ukuran yang mirip (Nurcholis et al., 2012, 2017b), hal tersebut yang memungkinkan produktivitas rimpang tidak berbeda nyata. Selain itu, temu ireng dan temulawak memiliki senyawa penanda yang sama yaitu kurkuminoid (Nurcholis et al., 2016a; c). Hal tersebut mengindikasikan bahwa proses metabolisme dimungkinkan serupa antara temu ireng dan temulawak, minimal dalam biosintesis senyawa kurmuninoid. Dengan demikian, kondisi lingkungan tertentu (misalnya dalam penelitian ini di Cianjur dan Sukabumi) dapat menginduksi berbagai enzim dan metabolit dalam proses metabolisme yang serupa, sehingga produktivitas rimpang temu ireng dan temulawak tidak berbeda nyata.

Genotipe G7 memiliki rata-rata laju fotosintesis tertinggi di semua lokasi sebesar $18.06 \mu \mathrm{mol} \mathrm{CO} \mathrm{CO}^{-2} \mathrm{~s}^{-1}$ meskipun tidak berbeda nyata $(\mathrm{p}<0.05)$ dengan sampel genotipe dan kontrol varietas lainnya (Tabel 4). G18, Cursina 1, dan G2 merupakan genotipe yang memiliki

Tabel 2. Analisis ragam AMMI2 20 genotipe temu hitam dan 3 varietas temulawak di tiga lokasi untuk produktivitas rimpang dan laju fotosintesis

\begin{tabular}{|c|c|c|c|c|c|}
\hline Sumber keragaman & $\mathrm{db}$ & JK & KT & F-hitung & Nilai p \\
\hline \multicolumn{6}{|c|}{ Produktivitas rimpang } \\
\hline Lokasi & 2 & $14,632,097$ & $7,316,049$ & 185.9434 & $<0.001$ \\
\hline Ulangan/Lokasi & 6 & 236,073 & 39,346 & 2.0210 & 0.067 \\
\hline Genotipe & 22 & 927,919 & 42,178 & 0.7769 & 0.734 \\
\hline Genotipe x Lokasi & 44 & $2,388,643$ & 54,287 & 2.7900 & $<0.001$ \\
\hline $\mathrm{PC} 1$ & 23 & $2,104,941$ & 91,519 & 4.7000 & $<0.001$ \\
\hline PC2 & 21 & 283,702 & 13,510 & 0.6900 & 0.837 \\
\hline Galat & 132 & $2,568,745$ & 19,460 & & \\
\hline \multicolumn{6}{|c|}{ Laju fotosintesis } \\
\hline Lokasi & 2 & 858.52 & 429.26 & 21.6726 & $<0.010$ \\
\hline Ulangan/Lokasi & 6 & 118.84 & 19.81 & 8.4253 & $<0.001$ \\
\hline Genotipe & 22 & 73.13 & 3.32 & 0.6402 & 0.869 \\
\hline Genotipe x Lokasi & 44 & 228.46 & 5.19 & 2.2086 & $<0.001$ \\
\hline PC1 & 23 & 188.26 & 8.19 & 3.4800 & $<0.001$ \\
\hline PC2 & 21 & 40.20 & 1.91 & 0.8100 & 0.704 \\
\hline Galat & 132 & 310.31 & 2.35 & & \\
\hline
\end{tabular}

Keterangan: $\mathrm{db}=$ derajat bebas; $\mathrm{JK}=$ jumlah kuadrat; $\mathrm{KT}=$ kuadrat tengah 
Tabel 3. Produktivitas rimpang 20 genotipe temu hitam dan 3 varietas temulawak pada tiga lingkungan tumbuh

\begin{tabular}{|c|c|c|c|c|}
\hline \multirow{2}{*}{ Genotipe/Varietas } & Bogor & Cianjur & Sukabumi & \multirow{2}{*}{ Rerata } \\
\hline & \multicolumn{3}{|c|}{-----------------Produktivitas rimpang (g per rumpun)----------------- } & \\
\hline G1 & $547 b$ & $225 b$ & $240 \mathrm{a}$ & $337 \mathrm{a}$ \\
\hline G2 & $840 b$ & $117 b$ & $420 \mathrm{a}$ & $459 \mathrm{a}$ \\
\hline G3 & $980 \mathrm{a}$ & $154 b$ & $467 \mathrm{a}$ & $534 \mathrm{a}$ \\
\hline G4 & $1080 \mathrm{a}$ & $175 b$ & $453 \mathrm{a}$ & $570 \mathrm{a}$ \\
\hline G5 & $773 b$ & $167 b$ & $540 \mathrm{a}$ & $493 \mathrm{a}$ \\
\hline G6 & $540 \mathrm{~b}$ & $386 a$ & $647 a$ & $524 \mathrm{a}$ \\
\hline G7 & $1067 \mathrm{a}$ & $206 b$ & $420 \mathrm{a}$ & $564 a$ \\
\hline G8 & $1080 \mathrm{a}$ & $153 b$ & $453 a$ & $562 a$ \\
\hline G9 & $1033 a$ & $136 b$ & $520 \mathrm{a}$ & $563 a$ \\
\hline G10 & $827 b$ & $185 b$ & $420 \mathrm{a}$ & $477 \mathrm{a}$ \\
\hline G11 & $1140 \mathrm{a}$ & $175 b$ & $520 \mathrm{a}$ & $612 \mathrm{a}$ \\
\hline G12 & $920 a$ & $169 b$ & $467 a$ & $518 \mathrm{a}$ \\
\hline G13 & $927 \mathrm{a}$ & $153 b$ & $420 \mathrm{a}$ & $500 \mathrm{a}$ \\
\hline G14 & $900 a$ & $142 b$ & $393 a$ & $478 \mathrm{a}$ \\
\hline G15 & $500 \mathrm{~b}$ & $219 b$ & $300 \mathrm{a}$ & $340 \mathrm{a}$ \\
\hline G16 & $740 \mathrm{~b}$ & $175 b$ & $347 \mathrm{a}$ & $420 \mathrm{a}$ \\
\hline G17 & $853 b$ & $158 b$ & $460 \mathrm{a}$ & $490 \mathrm{a}$ \\
\hline G18 & $1053 a$ & $158 b$ & $263 a$ & $492 \mathrm{a}$ \\
\hline G19 & $800 \mathrm{~b}$ & $189 b$ & $460 \mathrm{a}$ & $483 a$ \\
\hline G20 & $780 \mathrm{~b}$ & $141 b$ & $360 \mathrm{a}$ & $427 \mathrm{a}$ \\
\hline Cursina 1 & $647 b$ & $257 b$ & $347 \mathrm{a}$ & $417 \mathrm{a}$ \\
\hline Cursina 2 & $700 \mathrm{~b}$ & $404 a$ & $427 \mathrm{a}$ & $510 \mathrm{a}$ \\
\hline Cursina 3 & $660 \mathrm{~b}$ & $378 \mathrm{a}$ & $473 a$ & $504 a$ \\
\hline Rerata & $843 \mathrm{~A}$ & $201 \mathrm{C}$ & 427B & \\
\hline
\end{tabular}

Keterangan: Angka yang diikuti oleh huruf kecil yang sama pada kolom yang sama dan angka yang diikuti oleh huruf kapital pada baris yang sama menunjukkan tidak berbeda nyata berdasarkan uji lanjut Scott-Knott pada taraf uji 5\%

laju fotosintesis tertinggi untuk masing-masing wilayah secara berurutan dari Bogor, Cianjur, dan Sukabumi. Seperti halnya dengan produktivitas rimpang, pada karakter laju fotosintesis tertinggi terjadi di lokasi Bogor diikuti Sukabumi dan Cianjur.

Produktivitas rimpang dan laju fotosintesis tertinggi terjadi di Bogor dibandingkan lokasi Sukabumi dan Cianjur (Tabel 3 dan 4). Lokasi Bogor memiliki ketinggian yang lebih rendah dan suhu rata-rata per bulan yang lebih tinggi dibandingkan Cianjur dan Sukabumi (Tabel 1). Peningkatan laju fotosintesis mengindikasikan terjadinya peningkatan $\mathrm{CO}_{2}$ atmosfer sehingga suhu lebih tinggi dilokasi Bogor. Peningkatan $\mathrm{CO}_{2}$ atmosfer berkontribusi nyata dalam peningkatan biomasa (Lenka et al., 2020). Penelitian lain menunjukkan bahwa produktivitas rimpang pada tanaman Lolium arundinaceum dipengaruhi oleh suhu (Saxena et al., 2014). Dengan demikian, suhu dan $\mathrm{CO}_{2}$ atmosfer dimungkinkan sebagai faktor abiotik yang menginduksi mekanisme metabolisme bagaimana rimpang temu hitam diproduksi lebih besar dibandingkan di lokasi Cianjur dan Sukabumi.

Pengujian multilokasi merupakan tahapan penting dalam mengembangkan varietas tanaman temu hitam, yaitu menguji beberapa genotipe unggul pada beberapa lokasi pengujian. Penelitian ini dilakukan untuk mengevaluasi 20 genotipe temu hitam yang ditanam di tiga lokasi budidaya dengan informasi lokasi tersaji pada Tabel 1. Hasil pengujian multilokasi dapat digunakan untuk mengindentifikasi interaksi genotipe dan lingkungan yang dapat memberikan informasi genotipe yang mampu beradaptasi secara luas atau spesifik lokasi (Bocianowski et al., 2020). Analisis data uji multilokasi dapat dilakukan dengan menggunakan analisis AMMI yang dapat memvisualisasikan dalam bentuk biplot antara genotipe dan lingkungan pengujian (Dewi et al., 2015). Suatu genotipe dikatakan stabil jika dekat dengan sumbu, namun jika genotipe jauh dari sumbu dan dekat dengan garis lokasi maka dikatakan spesifik lokasi tersebut. 
Tabel 4. Laju fotosintesis 20 genotipe temu hitam dan 3 varietas temulawak pada tiga lingkungan tumbuh

\begin{tabular}{|c|c|c|c|c|}
\hline \multirow{2}{*}{ Genotipe/Varietas } & Bogor & Cianjur & Sukabumi & \multirow{2}{*}{ Rerata } \\
\hline & \multicolumn{3}{|c|}{ 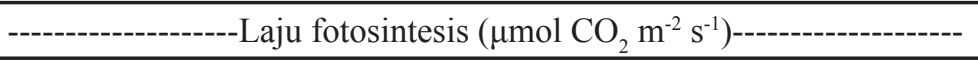 } & \\
\hline G1 & $21.46 \mathrm{a}$ & $13.71 b$ & $15.39 \mathrm{a}$ & $16.85 \mathrm{a}$ \\
\hline G2 & $20.63 a$ & $14.18 b$ & $18.30 \mathrm{a}$ & $17.72 \mathrm{a}$ \\
\hline G3 & $17.98 \mathrm{a}$ & $13.51 b$ & $16.94 \mathrm{a}$ & $16.14 \mathrm{a}$ \\
\hline G4 & $19.73 \mathrm{a}$ & $14.62 b$ & $16.72 \mathrm{a}$ & $17.02 \mathrm{a}$ \\
\hline G5 & $19.60 \mathrm{a}$ & $14.37 b$ & $16.04 \mathrm{a}$ & $16.67 \mathrm{a}$ \\
\hline G6 & $19.16 \mathrm{a}$ & $13.83 b$ & $16.33 \mathrm{a}$ & $16.44 \mathrm{a}$ \\
\hline G7 & $21.88 \mathrm{a}$ & $14.76 \mathrm{~b}$ & $17.55 \mathrm{a}$ & $18.06 \mathrm{a}$ \\
\hline G8 & $19.79 \mathrm{a}$ & $14.26 b$ & $16.97 \mathrm{a}$ & $17.00 \mathrm{a}$ \\
\hline G9 & $17.80 \mathrm{a}$ & $14.40 \mathrm{~b}$ & $16.56 \mathrm{a}$ & $16.25 \mathrm{a}$ \\
\hline G10 & $20.86 a$ & $14.11 b$ & $16.18 \mathrm{a}$ & $17.05 \mathrm{a}$ \\
\hline G11 & $19.75 \mathrm{a}$ & $14.52 b$ & $16.48 \mathrm{a}$ & $16.91 \mathrm{a}$ \\
\hline G12 & $18.21 \mathrm{a}$ & $14.23 b$ & $16.47 \mathrm{a}$ & $16.31 \mathrm{a}$ \\
\hline G13 & $19.62 \mathrm{a}$ & $14.17 b$ & $16.44 \mathrm{a}$ & $16.74 \mathrm{a}$ \\
\hline G14 & $18.20 \mathrm{a}$ & $13.90 \mathrm{~b}$ & $15.68 \mathrm{a}$ & $15.92 \mathrm{a}$ \\
\hline G15 & $21.55 \mathrm{a}$ & $14.63 b$ & $17.30 \mathrm{a}$ & $17.83 \mathrm{a}$ \\
\hline G16 & $20.39 a$ & $15.43 b$ & $16.15 \mathrm{a}$ & $17.32 \mathrm{a}$ \\
\hline G17 & $20.63 a$ & $13.03 b$ & $15.15 \mathrm{a}$ & $16.27 \mathrm{a}$ \\
\hline G18 & $22.41 \mathrm{a}$ & $14.68 b$ & $16.65 \mathrm{a}$ & $17.92 \mathrm{a}$ \\
\hline G19 & $18.96 \mathrm{a}$ & $12.95 \mathrm{~b}$ & $17.38 \mathrm{a}$ & $16.43 \mathrm{a}$ \\
\hline G20 & $19.27 \mathrm{a}$ & $13.84 b$ & $17.23 \mathrm{a}$ & $16.78 \mathrm{a}$ \\
\hline Cursina 1 & $17.74 \mathrm{a}$ & $18.09 \mathrm{a}$ & $16.68 \mathrm{a}$ & $17.50 \mathrm{a}$ \\
\hline Cursina 2 & $17.89 \mathrm{a}$ & $17.58 \mathrm{a}$ & $17.21 \mathrm{a}$ & $17.56 \mathrm{a}$ \\
\hline Cursina 3 & $16.77 \mathrm{a}$ & $17.42 \mathrm{a}$ & $16.82 \mathrm{a}$ & $17.00 \mathrm{a}$ \\
\hline Rerata & $19.58 \mathrm{~A}$ & $14.62 \mathrm{C}$ & $16.64 \mathrm{~B}$ & \\
\hline
\end{tabular}

Keterangan: Angka yang diikuti oleh huruf kecil yang sama pada kolom yang sama dan angka yang diikuti oleh huruf kapital pada baris yang sama menunjukkan tidak berbeda nyata berdasarkan uji lanjut Scott-Knott pada taraf uji 5\%

Gambar 1 menunjukkan hasil biplot pengaruh interaksi model AMMI2 pada karakter produktivitas rimpang dan laju fotosintesis dari 20 genotipe temu hitam dan 3 varietas kontrol temulawak yang diuji pada lokasi Bogor, Cianjur, dan Sukabumi. Kontribusi keragaman pengaruh interaksi yang mampu diterangkan oleh PC1 dan PC2 untuk produktivitas rimpang adalah $88.1 \%$ dan $11.9 \%$, sementara pada karakter laju fotosintesis masing-masing secara berurutan adalah $82.4 \%$ dan $17.6 \%$. Keragaman karakter produktivitas rimpang dan laju fotosintesis dapat dijelaskan dengan lebih dominan oleh PC1 dibandingkan dengan PC2. Stabilitas 20 genotipe temu hitam dan 3 varietas temulawak pada karakter produktivitas rimpang dan laju fotosintesis tersaji pada Gambar 1. Terdapat 9 genotipe (G2, G10, G12, G13, G14, G16, G17, G19, dan G20) termasuk dalam kategori stabil untuk produktivitas rimpang, sementara pada laju fotosintesis yang stabil sebanyak 7 genotipe (G4, G5, G6, G8, G11, G13, dan
G14). Genotipe G7, G8, dan G4 merupakan genotipe yang spesifik pada lokasi Bogor untuk produktivitas rimpang. Lokasi Cianjur teridentifikasi genotipe G1 dan G15 serta tiga varietas temulawak Cursina 1, Cursina 2, dan Cursina 3 yang spesifik dalam menghasilkan karakter produktivitas rimpang. Genotipe G5 merupakan spesifik lokasi Sukabumi dalam produktivitas rimpang temu hitam. Sementara untuk karakter laju fotosintesis, genotipe G7, G15, dan G10 spesifik lokasi Bogor, tiga varietas temulawak Cursina 1, Cursina 2, dan Cursina 3 spesifik lokasi Cianjur. Adapun G3 dan G20 spesifik lokasi Sukabumi. Genotipe temu hitam yang digunakan dalam penelitian ini berasal dari 20 lokasi yang diseleksi berdasarkan karakter agro-morfologi (Khumaida et al., 2019), kandungan metabolit sekunder dan aktivitas farmakologi (Nurcholis et al., 2016b; c, 2017a). Genotipe yang spesifik lokasi dan stabil dapat digunakan sebagai bahan untuk pengembangan temu hitam menjadi varietas tanaman obat yang unggul pada penelitian selanjutnya. 

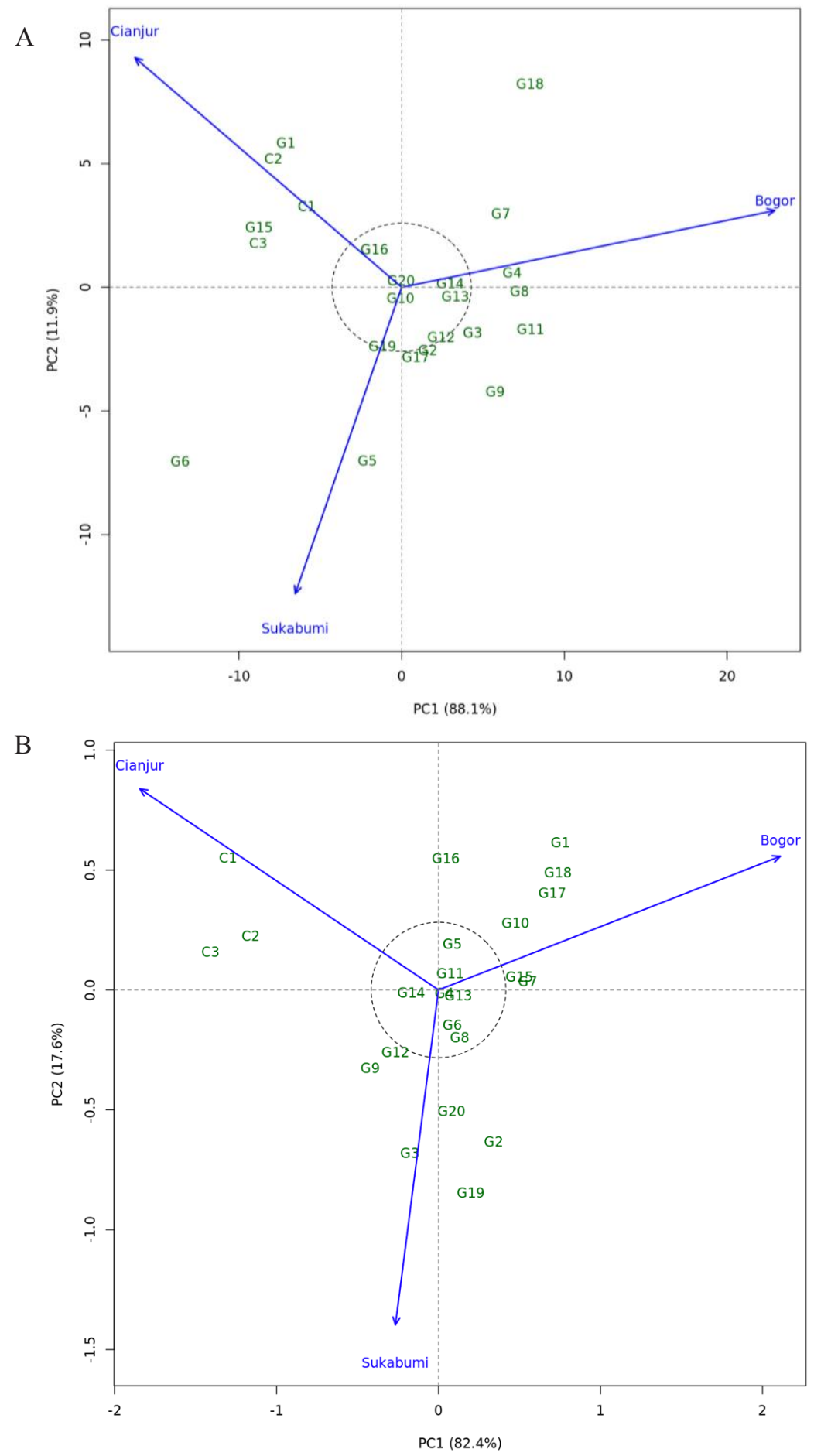

Gambar 1. Biplot pengaruh interaksi model AMMI2 pada karakter produktivitas rimpang per rumpun (A) dan laju fotosintesis (B) 20 genotipe temu hitam (G1-G20) dan 3 varietas temulawak (C1-C3 = Cursina 1, 2 dan 3) yang diuji pada tiga lokasi berbeda

\section{KESIMPULAN}

Produktivitas rimpang dan laju fotosintesis merupakan karakter yang memiliki interaksi genotipe x lingkungan yang sangat nyata. Bogor merupakan lokasi terbaik tanaman temu hitam menghasilkan produktivitas rimpang dan laju fotosintesis tertinggi dibandingkan Cianjur dan Sukabumi. Terdapat 9 genotipe (G2, G10, G12, G13, G14, G16, G17, G19, dan G20) untuk karakter produktivitas rimpang dan
7 genotipe (G4, G5, G6, G8, G11, G13, dan G14) untuk karakter laju fotosintesis yang dikategorikan stabil pada tiga lingkungan pengujian. Pada karakter produktivitas rimpang, genotipe spesifik lokasi merupakan G7, G8, dan G4 di Bogor, G5 di Sukabumi, G1, G15, Cursina 1, Cursina 2, dan Cursina 3 di Cianjur. Sementara untuk karakter laju fotosintesis, G7, G15 dan G10 spesifik di Bogor, Cursina 1, Cursina 2, dan Cursina 3 spesifik lokasi Cianjur, genotipe G3 dan G20 spesifik lokasi Sukabumi. 


\section{UCAPAN TERIMA KASIH}

Penelitian ini didanai oleh Kementrian Riset Teknologi dan Pendidikan Tinggi Republik Indonesia melalui program kegiatan Penelitian Terapan Unggulan Perguruan Tinggi (No. 4324/IT3.L1/PN/2019), Institut Pertanian Bogor. Penulis mengucapkan terima kasih pada LPPM IPB University atas bantuan administrasi selama pelaksanaan penelitian.

\section{DAFTAR PUSTAKA}

Aarthi, S., J. Suresh, N.K. Leela, D. Prasath. 2020. Multi environment testing reveals genotype-environment interaction for curcuminoids in turmeric (Curcuma longa L.). Indust. Crops Prod. 145:112090.

Akarchariya, N., S. Sirilun, J. Julsrigival, S. Chansakaowa. 2017. Chemical profiling and antimicrobial activity of essential oil from Curcuma aeruginosa Roxb., Curcuma glans K. Larsen \& J. Mood and Curcuma cf. xanthorrhiza Roxb. collected in Thailand. Asian Pac. J. Trop. Biomed. 7:881-885.

Bocianowski, J., A. Liersch, K. Nowosad. 2020. Genotype by environment interaction for alkenyl glucosinolates content in winter oilseed rape (Brassica napus L.) using additive main effects and multiplicative interaction model. Curr. Plant Biol. 21:100137.

Chidburee, A., W. Bundittaya, C. Suwanthada, O. Norikuni, K. Sueyoshi, T. Ohyama, S. Ruamrungsri. 2007. Effects of red light on growth, photosynthesis and food reserves in Curcuma alismatifolia Gagnep. Thai J. Agric. Sci. 40:57-63.

Dewi, S.M., Sobir, M. Syukur. 2015. Interaksi genotipe x lingkungan hasil dan komponen hasil 14 genotipe tomat di empat lingkungan dataran rendah. J. Agron. Indonesia 43:59-65.

Khumaida, N., M. Syukur, M. Bintang, W. Nurcholis. 2019. Phenolic and flavonoid content in ethanol extract and agro-morphological diversity of Curcuma aeruginosa accessions growing in West Java, Indonesia. Biodiversitas J. Biol. Divers. 20:656-663.

Lenka, N.K., S. Lenka, J.K. Thakur, D.S. Yashona, A.K. Shukla, R. Elanchezhian, K.K. Singh, A.K. Biswas, A.K.Patra. 2020. Carbon dioxide and temperature elevation effects on crop evapotranspiration and water use efficiency in soybean as affected by different nitrogen levels. Agric. Water Manag. 230:105936.
Miao, Y., Q. Bi, H. Qin, X. Zhang, N. Tan. 2020. Moderate drought followed by re-watering initiates beneficial changes in the photosynthesis, biomass production and Rubiaceae-type cyclopeptides (RAs) accumulation of Rubia yunnanensis. Indust. Crops Prod. 148:112284.

Nurcholis, W., L. Ambarsari, E.D. Purwakusumah. 2016 a. Curcumin analysis and cytotoxic activities of some Curcuma xanthorrhiza Roxb. Accessions. Int. J. Pharm. Tech. Res. 9:175-180.

Nurcholis, W., H. Hartanti, S. Suryani, B.P. Priosoeryanto. 2019. Evaluation of agro-morphological traits in 20 genotypes selected of Curcuma aeruginosa Roxb. Agrosainstek J. Ilmu Teknol. Pertan. 3:42-51.

Nurcholis, W., N. Khumaida, M. Syukur, M. Bintang. 2016b. Variability of total phenolic and flavonoid content and antioxidant activity among 20 Curcuma aeruginosa Roxb. accessions of Indonesia. Asian J. Biochem. 11:142-148.

Nurcholis, W., N. Khumaida, M. Syukur, M. Bintang. 2016c. Variability of curcuminoid content and lack of correlation with cytotoxicity in ethanolic extracts from 20 accessions of Curcuma aeruginosa RoxB. Asian Pacific J. Trop. Dis. 6:887-891.

Nurcholis, W., N. Khumaida, M. Syukur, M. Bintang. 2017a. Evaluation of free radical scavenging activity in ethanolic extract from promising accessions of Curcuma aeruginosa RoxB. Molekul 12:133-138.

Nurcholis, W., N. Khumaida, M. Syukur, M. Bintang. $2017 \mathrm{~b}$. Similarity analysis of 20 promising accessions of Curcuma aeruginosa Roxb. based on rhizome color, extract yield, and phytochemical contents. J. Agron. Indonesia 44: 315-321.

Nurcholis, W., A.A. Munshif, L. Ambarsari. 2018. Xanthorrhizol contents, $\alpha$-glucosidase inhibition, and cytotoxic activities in ethyl acetate fraction of Curcuma zanthorrhiza accessions from Indonesia. Rev. Bras. Farmacogn. 28:44-49.

Nurcholis, W., E.D. Purwakusumah, M. Rahardjo, L.K. Darusman. 2012. Variasi bahan bioaktif dan bioaktivitas tiga nomor harapan temulawak pada lokasi budidaya berbeda. J. Agron. Indonesia 40:153159.

Pavlović, I., P. Tarkowski, T. Prebeg, H. Lepeduš, B. Salopek-Sondi. 2019. Green spathe of peace lily (Spathiphyllum wallisii): An assimilate source for developing fruit. South African J. Bot. 124:54-62. 
Pusat Perlindungan Varietas Tanaman dan Perizinan Pertanian. 2019. Sistem Informasi Database Varietas Tanaman. Kementrian Pertan. Republik Indones. http://aplikasi.pertanian.go.id/varietas/tamu/utama. asp (accessed 7 February 2020).

Saxena, P., B. Huang, S.A. Bonos, W.A. Meyer. 2014. Photoperiod and temperature effects on rhizome production and tillering rate in tall fescue [Lolium arundinaceum (Schreb.) Darby.]. Crop Sci. 54:12051210 .
Sharifi, P., H. Aminpanah, R. Erfani, A. Mohaddesi, A. Abbasian. 2017. Evaluation of genotype $\times$ environment interaction in rice based on AMMI model in Iran. Rice Sci. 24:173-180.

Srivilai, J., P. Phimnuan, J. Jaisabai, N. Luangtoomma, N. Waranuch, N. Khorana, W. Wisuitiprot, C.N. Scholfield, K. Champachaisri, K. Ingkaninan. 2017. Curcuma aeruginosa Roxb. essential oil slows hairgrowth and lightens skin in axillae; a randomised, double blinded trial. Phytomedicine 25:29-38. 